\title{
Pengaruh motivasi, kepuasan, dan disiplin kerja terhadap kinerja karyawan pada PT. Indonesia Comnets Plus Medan
}

\author{
Deni Faisal Mirza; Titi Swarni Lumbantobing*; Heny Perary Menzez \\ Simanjuntak; Yosafati Giawa
}

\author{
Program Studi Manajemen Fakultas Ekonomi Universitas Prima Indonesia \\ *E-mail korespodensi : tititobing98@gmail.com
}

\begin{abstract}
The purpose of the implementation of the research is to understand the magnitude of the influence of free or independent variables of job satisfaction, work discipline and also motivation on performance generated by employees working in PT. Indonesia Comnets Plus. In the implementation of this study, the population used was 60 officers and while the sample was as many as 60 survey respondents. In the implementation of this research, the method used is a quantitative approach, and while for this research technique uses multiple linear analysis. The results of this research conducted show that simultaneously or together that variables are free or independent of job satisfaction, work discipline and also motivation contributes a significant influence on the performance produced by employees working in PT. Indonesia Comnets Plus, meanwhile, partially tested results showed that variables free or independent of job satisfaction, work discipline and motivation contributed significantly to the performance generated by employees working at PT. Indonesia Comnets Plus. The ongoing relationship between free or independent variables of job satisfaction, work discipline and also motivation on variables is bound or dependent from performance generated by employees working at PT. Indonesia Comnets Plus is very large.
\end{abstract}

Keywords: Motivation, Job satisfaction, Work discipline, Employee performance.

\begin{abstract}
Abstrak
Tujuan dari pelaksanaan penelitian ialah agar memahami besaran pengaruh dari variabel bebas atau independen dari kepuasan kerja, disiplin kerja dan juga motivasi pada kinerja yang dihasilkan oleh karyawan yang bekerja di PT. Indonesia Comnets Plus. Di dalam pelaksanaan penelitian ini, populasi yang dipergunakan ialah sebanyak 60 pegawai dan sedangkan sampelnya ialah sebanyak 60 responden penelitian. Di dalam pelaksanaan penelitian ini, metode yang dipergunakan ialah pendekatan kuantitatif, dan sedangkan untuk teknik penelitian ini mempergunakan analisis linear berganda. Hasil dari pelaksanaan penelitian ini dilaksanakan memperlihatkan bahwa secara simultan atau bersama-sama bahwa variabel bebas atau independen dari kepuasan kerja, disiplin kerja dan juga motivasi memberikan sumbangan pengaruh signifikan pada kinerja yang dihasilkan oleh karyawan yang bekerja di PT. Indonesia Comnets Plus, sementara itu hasil dari pengujian secara parsial memperlihatkan bahwa variabel bebas atau independen dari kepuasan kerja, disiplin kerja dan juga motivasi memberikan sumbangan pengaruh signifikan pada kinerja yang dihasilkan oleh karyawan yang bekerja di PT. Indonesia Comnets Plus. Hubungan yang berlangsung antara variabel bebas atau independen dari kepuasan kerja, disiplin kerja dan juga motivasi pada variabel terikat atau dependen dari kinerja yang dihasilkan oleh karyawan yang bekerja di PT. Indonesia Comnets Plus tersebut sangat besar.
\end{abstract}

Kata kunci: Motivasi, Kepuasan kerja, Disiplin kerja, Kinerja karyawan. 


\section{PENDAHULUAN}

Sekarang ini, perusahaan harus tepat membangun dan meningkatkan kinerja di dalam lingkungan pekerjaan itu sendiri. Untuk memacu kinerja karyawan diperlukan motivasi dari dalam diri karyawan, serta kepuasaan kerja karyawan terhadap pekerjaannya dan disiplin kerja setiap karyawan. Namun masih banyak masalah yang dihadapi oleh sumber daya manusia dalam perusahaan yang menyebabkan penurunan kinerja karyawan.

Melalui data yang diteliti beberapa tahun belakangan ini terlihat bahwa pekerjaan yang dilakukan oleh karyawan tidak dapat diselesaikan dengan baik sehingga membuat kinerja karyawan mengalami penurunan. Penurunan kinerja karyawan terjadi disebabkan oleh beberapa faktor kesalahan yang berpengaruh terhadap pencapaian target perusahaan.

Salah satu yang mempengaruhi menurunnya kinerja karyawan seperti Motivasi kerja. Karena saat motivasi kerja menurun maka seorang karyawan akan kehilangan semangat untuk tetap menghasilkan nilai positif dalam kerjanya. Pembagian bonus ataupun insentif lembur PT Indonesia Comnets Plus belum sesuai. membuat karyawan menjadi tidak termotivasi dalam melakukan dan menyelesaikan kerjaannya dengan baik. karyawan juga menjadi tidak termotivasi untuk mengambil kegiatan lembur karna menilai pembagian insentif lembur yang tidak sesuai sehingga mereka tidak termotivasi bekerja sampai lembur.

Selain itu Kepuasaan kerja juga sangat mempengaruhi kinerja karyawan. Tidak semua karyawan merasa puas dengan pekerjaan yang sedang mereka kerjakan. Sebagian karyawan menilai atasannya tidak memimpin dan mengarahkan dengan baik. Ada juga sebagian karyawan yang tidak merasa puas dengan sikap toleransi sesama rekan kerja karena kurangnya sikap yang atraktif dalam hal saling menolong .

Disiplin kerja juga sangat mempengaruhi kinerja karyawan. Sistem kedisiplinan kerja yang ada di PT Indonesia Comnets Plus belum sepenuhnya dilaksanakan dengan baik. Karyawan masih suka menunda pekerjaan yang diberikan oleh atasan dan sistem peraturan tepat waktu didalam perusahaan juga masi belum terlaksana dengan baik.

Berdasarkan latar belakang permasalahan yang terjadi pada perusahaan, maka dengan judul "Pengaruh motivasi, kepuasan dan disiplin kerja terhadap kinerja karyawan pada PT Indonesia Comnets Plus"

\section{LANDASAN TEORI}

\section{Teori tentang motivasi kerja}

Menurut Edy Sutrisno (2009:109),"Motivasi kerja mengasumsikan faktor yang mampu memberikan dorongan pada seorang individu dalam melaksanakan sebuah aktivitas atau kegiatan, dengan demikian motivasi didefinisikakn sebagai faktor yang menggerakkan perilaku dari seorang individu".

Menurut Stefan Ivanko (2016:131),"Motivasi energy atau keinginan dari seorang individu yang ditujukan atau diperuntukkan guna meraih tujuan tertentu".

Menurut Hamalik (2019:77),'Motivasi ialah berubahnya suatu gerakan atau energy yang ada pada seorang individu yang dikarakteristikkan dengan adanya reaksi dan perasaan guna meraih suatu tujuan yang ditetapkan".

\section{Teori tentang kepuasan}

Menurut Sutarto Wijono (2010:119),'Kepuasan ialah sebuah perasaan yang sifatnya membuat senang, kepuasan ini didefinisikan sebagai hasil yang berasal dari persepsi seorang individu tertentu dalam upaya menunaikan penyelesaian suatu 
kewajiban atau melaksanakan pemenutuhan kebutuhan guna meraih nilai-nilai kerja yang mengandung bobot kepentingan untuk seorang individu tersebut".

Menurut Vroom (2017:210),'Kepuasan kerja ialah suatu reaksi yang timbul dari para karyawan berkenaan dengan peran atau kewajiban yang menjadi tugasnya untuk melaksanakan pemenuhan kewajiban kerjanya".

Menurut Nanang Tegar (2019:67), kepuasan kerja ialah keadaan psikologi yang membuat senang yang ada pada para karyawan atau pegawai di dalam sebuah lingkungan kerja berkenaan dengan kebutuhan dan peran yang ditunaikan secara bagus".

\section{Tentang disiplin}

Menurut Hasibuan (2009:193), disiplin ialah kesediaan atau kesadaran yang ada pada seorang individu untuk mematuhi segala peraturan yang terdapat pada perusahaan dimana seorang individu tersebut berkerja dan juga norma-norma sosial yang ada di lingkungan kerja tersebut".

Menurut Arif Yusuf Hamali (2016:214) disiplin ialah sebuah kondisi yang kuat yang ada dan tumbuh pada diri seorang individu dan mampu mengakibatkan seorang individu tersebut mampu melaksanakan penyesuaian diri secara sukarela terhadap ketetapan dari peraturan dan juga nilai yang tinggi pada perilaku dan juga pekerjaan. Menurut T.Hani Handoko (2014:208) disiplin ialah aktivitas manajemen dalam melaksanakan standar keorganisasian".

\section{Teori tentang kinerja}

Menurut Emron Edison (2017:188),"Kinerja ialah suatu hasil atas serangkaian proses yang merujuk atau bisa dilaksanakan pengukuruan untuk periode waktu yang ditetapkan yang berlandaskan terhadap kesepakatan dan juga ketentuan yang sudah dipertetapkan.

Menurut Kreitner dan Kinicki (2018:10),"Kinerja ialah sebuah sirkulasi atau rangkaian yang terus menerus dalam upaya untuk melaksanakan perbaikan terhadap kinerja yang ditetapkan dengan cara melaksanakan penguatan positif, penghargaan, coaching, umpan balik dan juga tujuan.

Menurut Wilson bangun (2012:231),'Kinerja iala hasil dari suatu kinerja yang diraih oleh seorang individu yang merujuk pada persyaratan yang ada pada jenis pekerjaan tersebut.

\section{METODE}

\section{Populasi dan sampel}

Menurut Sugiyono (2013:80) menyatakan bahwa populasi mengasumsikan bahwa suatu wilayah yang digeneralisasikan berdasarkan atas subjek dan objek yang memiliki kuantitas serta kualitas tertentu yang dipertetapkan oleh pelaksana penelitian untuk tujuan didalami lebih jauh serta dilaksananan penarikan simpulan. Populasi yang dipergunakan dalam pelaksanaan penelitian ialah karyawan atau pegawai yang bekerja di PT.Indonesia Comnets Plus" sebanyak 60 karyawan.

\section{Sampel}

Menurut Sugiyono (2017:116), sampel adalah bagian dari jumlah dan karakteristik yang dimiliki oleh populasi tersebut.Teknik pengambilan sampel dalam penelitian ini dengan menggunakan Sampel Jenuh, dimana seluruh jumlah populasi digunakan sebagai sampel dalam penelitian ini. Maka sampel dalam penelitian ini sebanyak 60 orang karyawan PT. Indonesia Comnets Plus" Medan dan mengambil sebanyak 30 orang karyawan PT.Rayateh utama Teladan Canggih Medan sebagai uji validitas dan reliabilitas. 


\section{Teknik pengumpulan data}

Teknik pengumpulan data dalam penelitian ini dilakukan dengan cara: 1).Wawancara, 2).Observasi/pengamatan, 3).Angket/kuesioner.

Tabel 1. Defenisi operasional

\begin{tabular}{|c|c|c|c|}
\hline Variabel & Definisi Variabel & Indikator Variabel & $\begin{array}{c}\text { Skala } \\
\text { Pengatura } \\
\text { n }\end{array}$ \\
\hline $\begin{array}{l}\text { Motivasi } \\
\left(\mathrm{X}_{1}\right)\end{array}$ & $\begin{array}{l}\text { Motivasi kerja ialah faktor yang } \\
\text { mampu memberikan dorongan pada } \\
\text { seorang individu dalam } \\
\text { melaksanakan sebuah aktivitas atau } \\
\text { kegiatan, dengan demikian motivasi } \\
\text { didefinisikan sebagai faktor yang } \\
\text { menggerakkan perilaku dari seorang } \\
\text { individu }\end{array}$ & $\begin{array}{ll}\text { 1. } & \text { Prestasi } \\
\text { 2. Tanggung jawab } \\
\text { 3. Gaji } \\
\text { 4. Pekerjaan itu } \\
\text { sendiri }\end{array}$ & $\begin{array}{l}\text { Skala } \\
\text { Likert }\end{array}$ \\
\hline $\begin{array}{l}\text { Kepuasan } \\
\left(\mathrm{X}_{2}\right)\end{array}$ & $\begin{array}{l}\text { Kepuasan ialah sebuah perasaan yang } \\
\text { sifatnya membuat senang, kepuasan } \\
\text { ini didefinisikan sebagai hasil yang } \\
\text { berasal dari persepsi seorang individu } \\
\text { tertentu dalam upaya menunaikan } \\
\text { penyelesaian suatu kewajiban atau } \\
\text { melaksanakan pemenutuhan } \\
\text { kebutuhan guna meraih nilai-nilai } \\
\text { kerja yang mengandung bobot } \\
\text { kepentingan untuk seorang individu } \\
\text { tersebut }\end{array}$ & $\begin{array}{l}\text { 1. Hubungan } \\
\text { antara manajer } \\
\text { dengan karyawan } \\
\text { 2. Faktor fisik dan } \\
\text { kondisi kerja } \\
\text { 3. Hubungan } \\
\text { sosial diantara } \\
\text { karyawan } \\
\text { 4. Sikap orang } \\
\text { terhadap pekerjaan } \\
\text { 5. Usia dengan } \\
\text { pekerjaan }\end{array}$ & $\begin{array}{l}\text { Skala } \\
\text { Likert }\end{array}$ \\
\hline $\begin{array}{l}\text { Disiplin } \\
\text { Kerja } \\
\left(\mathrm{X}_{3}\right)\end{array}$ & $\begin{array}{l}\text { Disiplin ialah kesediaan atau } \\
\text { kesadaran yang ada pada seorang } \\
\text { individu untuk mematuhi segala } \\
\text { peraturan yang terdapat pada } \\
\text { perusahaan dimana seorang individu } \\
\text { tersebut berkerja dan juga norma- } \\
\text { norma sosial yang ada di lingkungan } \\
\text { kerja tersebut }\end{array}$ & $\begin{array}{l}\text { 1. Teladan pimpinan } \\
\text { 2. Keadilan } \\
\text { 3. Sanksi hukuman } \\
\text { 4. Ketegasan }\end{array}$ & $\begin{array}{l}\text { Skala } \\
\text { Likert }\end{array}$ \\
\hline $\begin{array}{l}\text { Kinerja } \\
\text { Karyawa } \\
\mathrm{n}(\mathrm{Y})\end{array}$ & $\begin{array}{l}\text { Kinerja ialah suatu hasil atas } \\
\text { serangkaian proses yang merujuk } \\
\text { atau bisa dilaksanakan pengukuruan } \\
\text { untuk periode waktu yang ditetapkan } \\
\text { yang berlandaskan terhadap } \\
\text { kesepakatan dan juga ketentuan yang } \\
\text { sudah dipertetapkan }\end{array}$ & $\begin{array}{ll}\text { 1. } & \text { Jumlah Pekerjaan } \\
\text { 2. Kualitas Pekerjaan } \\
\text { 3. Ketepatan Waktu } \\
\text { 4. Kehadiran } \\
\text { 5. kemampuan kerja } \\
\text { sama }\end{array}$ & $\begin{array}{l}\text { Skala } \\
\text { Likert }\end{array}$ \\
\hline
\end{tabular}

Sumber: Data diolah,2020

\section{HASIL DAN PEMBAHASAN}

\section{Analisis statistik deskriptif}

Dibawah ini adalah statistik deskriptif yang berupa jawaban dari standar deviasi, rata-rata, maksimum dan minimum dari responden, hal ini bisa ditinjau berdasarkan pada tabel berikut : 
Tabel 2. Hasil uji statistik deskriptif

\begin{tabular}{|c|c|c|c|c|c|c|}
\hline & & \multicolumn{4}{|c|}{ Descriptive Statistics } & \multirow{3}{*}{$\begin{array}{c}\text { Std. } \\
\text { Deviation } \\
\text { Statistic }\end{array}$} \\
\hline & $\mathbf{N}$ & Minimum & Maximum & \multicolumn{2}{|c|}{ Mean } & \\
\hline & & & & Statistic & $\begin{array}{c}\text { Std. } \\
\text { Error }\end{array}$ & \\
\hline Moti & 60 & 20 & 35 & 26.33 & .448 & 3.472 \\
\hline Kepı & 60 & 22 & 48 & 36.77 & .630 & 4.879 \\
\hline Disiplin $\mathrm{Ke}$ & 60 & 23 & 40 & 32.23 & .539 & 4.176 \\
\hline Kinerja Karyawan & 60 & 25 & 45 & 37.27 & .482 & 3.732 \\
\hline Valid N (listwise) & 60 & & & & & \\
\hline
\end{tabular}

Sumber: Data diolah,2020

Berdasarkan tabel diatas memperlihatkan bahwa pada variabel motivasi $\left(\mathrm{X}_{1}\right)$ memiliki jawaban paling kecil dari responden ialah senilai 20, jawaban paling tinggi ialah senilai 35, rata-rata atau mean dari total jawaban ialah senilai 26,33 dan sedangkan untuk standar deviasi ialah senilai 3,472. Variabel kepuasan kerja $\left(\mathrm{X}_{2}\right)$ memiliki jawaban paling kecil dari responden ialah senilai 22, jawaban paling tinggi ialah senilai 48, rata-rata atau mean dari total jawaban ialah senilai 36.77 dan sedangkan untuk standar deviasi ialah senilai 4,879. Variabel disiplin kerja $\left(\mathrm{X}_{3}\right)$ memiliki jawaban paling kecil dari responden ialah senilai 23, jawaban paling tinggi ialah senilai 40, rata-rata atau mean dari total jawaban ialah senilai 32,23 dan sedangkan untuk standar deviasi ialah senilai 4,176. Variabel kinerja karyawan (Y) memiliki jawaban paling kecil dari responden ialah senilai 25 , jawaban paling tinggi ialah senilai 45 , rata-rata atau mean dari total jawaban ialah senilai 37,27 dan sedangkan untuk standar deviasi ialah senilai 3,732.

\section{Hasil uji asumsi klasik}

\section{Uji normalitas}

Berdasarkan hasil uji normalitas menggunakan grafik histogram pada Gambar 1 diketahui bahwa distribusi data memiliki kurva berbentuk lonceng dimana distribusi data tidak menceng kekiri maupun kekanan. Hal ini menunjukan bahwa data telah terdistribusi secara normal.

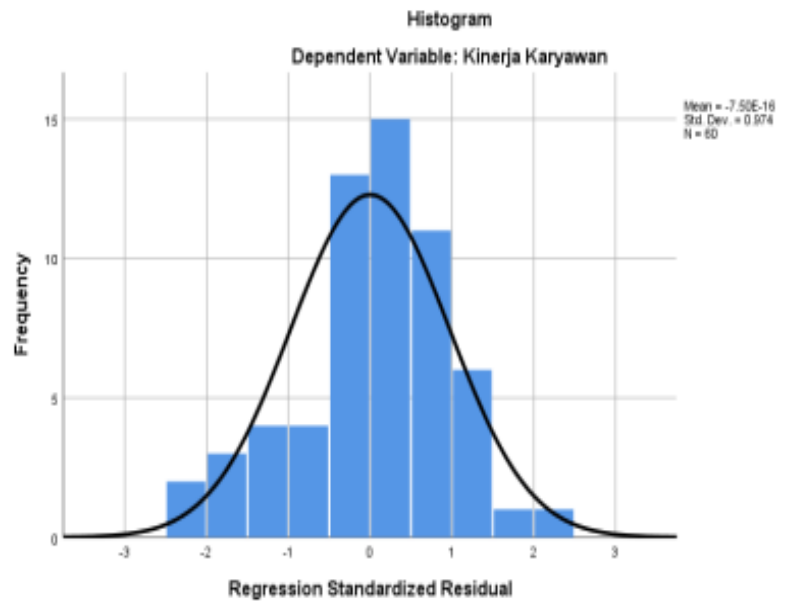

Sumber: Data diolah,2020

Gambar 1. Histogram

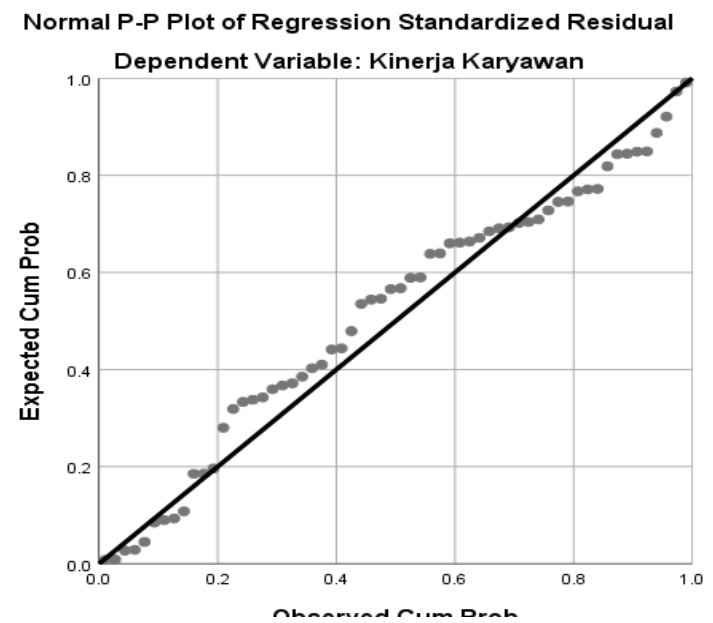

Sumber: Data diolah, 2020

Gambar 2. P-Plots 
Selain itu, penelitian ini juga melakukan uji Grafik P-Plots pada Gambar 2 tersebut di atas bisa ditinjau bahwa grafik histogram titik menyebar di sekitar diagonal dan penyebaran dari titik-titik tersebut mengikuti pada arah dari garis diagonal dengan demikian bisa dihasilkan suatu simpulan bahwa data model dari regresi tersebut memiliki distribusi yang normal.

\section{Hasil uji normalitas}

Selanjutnya, dilakukan pengujian normalitas dengan mempergunakan pengujian kolmogorov-smirnov memperlihatkan bahwa nilai dari signifikannya ialah senilai $0.183>0,05$, dengan demikian hasil dari pengujian kolmogorov-smirnov memperlihatkan bahwa data tersebut memiliki distribusi yang normal.

Tabel 3. One - Sample Kolmogorov-Smirnov Test

\begin{tabular}{|c|c|c|}
\hline One-Sample K & mogoroy-Smir & $\begin{array}{l}\text { vest } \\
\text { Unstandardized } \\
\text { Residual }\end{array}$ \\
\hline $\mathrm{N}$ & & 60 \\
\hline \multirow{2}{*}{ Normal Parameters ${ }^{a, b}$} & Mean & .0000000 \\
\hline & Std. Deviation & 3.04257796 \\
\hline \multirow[t]{3}{*}{ Most Extreme Differences } & Absolute & .103 \\
\hline & Positive & .078 \\
\hline & Negative & -.103 \\
\hline Test Statistic & & .103 \\
\hline Asyman-Sig. (2-tailed) & & $.183^{\circ}$ \\
\hline
\end{tabular}

Sumber: Data diolah,2020

\section{Uji multikolinearitas}

Berdasarkan uji multikolinearitas yang ditunjukkan pada Tabel 4 yang di atas bisa dlihat bahwa keseluruhan dari variabel bebas atau independen mempunyai nilai dari tolerance yang lebih tinggi dibanding pada 0.1 , dan sedangkan keseluruhan dari variabel bebas atau independen tersebut mempunyai nilai VIF yang tidak lebih tinggi dibanding pada 10. Hal semacam ini memperlihatkan bahwa tidak berlangsung permasalahan yang berkenaan dengan multikolinearitas yang ada antar variabel bebas atau independen di dalam permodelan regresi tersebut.

Tabel 4. Hasil uji multikolinearitas

\begin{tabular}{|c|c|c|c|c|c|c|c|c|}
\hline & \multirow{3}{*}{ Model } & \multicolumn{5}{|c|}{ Coefficients ${ }^{\mathbf{a}}$} & \multirow{2}{*}{\multicolumn{2}{|c|}{$\begin{array}{l}\text { Collinearity } \\
\text { Statistics }\end{array}$}} \\
\hline & & \multicolumn{2}{|c|}{$\begin{array}{c}\text { Unstandardize } \\
\text { d } \\
\text { Coefficients }\end{array}$} & \multirow{2}{*}{$\begin{array}{c}\begin{array}{c}\text { Standardize } \\
\text { d } \\
\text { Coefficients }\end{array} \\
\text { Beta }\end{array}$} & \multirow{2}{*}{$\mathbf{t}$} & \multirow{2}{*}{ Sig. } & & \\
\hline & & B & $\begin{array}{l}\text { Std. } \\
\text { Error }\end{array}$ & & & & $\begin{array}{c}\text { Toleran } \\
\text { ce }\end{array}$ & VIF \\
\hline \multirow[t]{4}{*}{$\overline{1}$} & (Constant) & 27.418 & 4.952 & & 5.536 & .000 & & \\
\hline & Motivasi & -.278 & .119 & -.259 & -2.340 & .023 & .972 & 1.029 \\
\hline & $\begin{array}{l}\text { Kepuasan } \\
\text { Kerja }\end{array}$ & .190 & .091 & .249 & 2.083 & .042 & .832 & 1.202 \\
\hline & $\begin{array}{l}\text { Disiplin } \\
\text { Kerja }\end{array}$ & .316 & .107 & .353 & 2.942 & .005 & .824 & 1.213 \\
\hline
\end{tabular}

a. DependentrVariable: KinerjarKaryawan

Sumber: Data diolah,2020 


\section{Uji heteroskedastisitas}

Berdasarkan pada grafik scatterplot yang di atas bisa dilihat bahwa data tersebut sifatnya menyebar dengan tidak beraturan, sehingga tidak menghasilkan sebuah pola serta menjauhi titik 0 , maka data tersebut dinyatakan terbebas dari heteroskedastisitas.

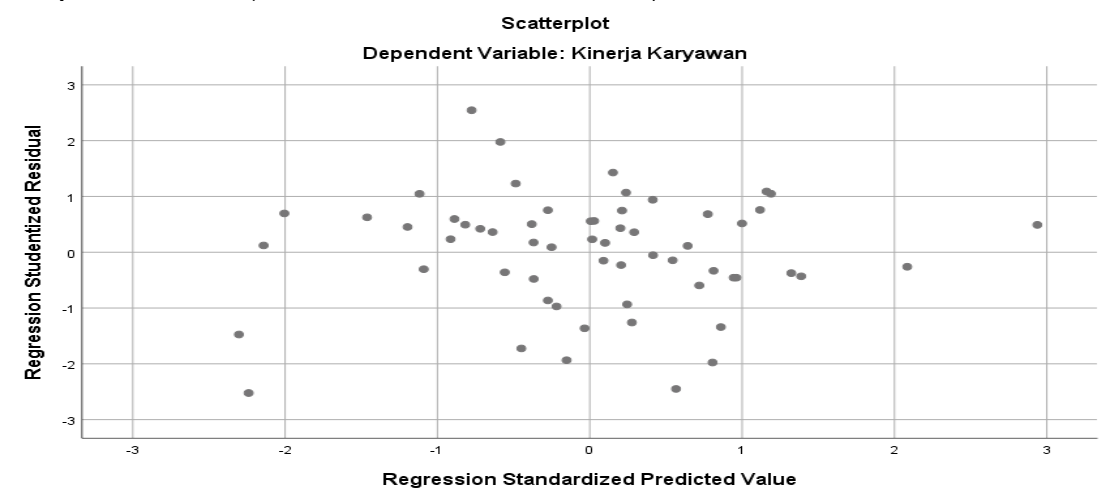

Sumber: Data diolah,2020

Gambar 3. Grafik scatterplot

\section{Hasil uji glejser}

Berdasarkan pada Tabel 5 menunjukan bahwa nilai signifikansi dari keseluruhan variabel bebas atau independen lebih tinggi dibanding pada 0.05 . Oleh karena itu, hasil dari pengujian Glejser tidak terdapat permasalahan yang berkenaan dengan heteroskedastisitas

Tabel 5. Hasil uji glejser

\begin{tabular}{llrrrrrr}
\hline \multirow{2}{*}{ Model } & \multicolumn{2}{c}{$\begin{array}{c}\text { Unstandardized } \\
\text { Coefficients }\end{array}$} & $\begin{array}{c}\text { Standardized } \\
\text { Coefficients } \\
\text { Beta }\end{array}$ & t & & Sig. \\
\cline { 2 - 4 } & B & \multicolumn{1}{c}{ Std. Error } & & & \\
\hline 1 & (Constant) & .621 & 3.008 & & .206 & .837 \\
& Motivasi & .116 & .072 & .212 & 1.604 & .114 \\
& Kepuasan Kerja & -.038 & .055 & -.097 & -.677 & .501 \\
& Disiplin Kerja & .002 & .065 & .005 & .035 & .972 \\
\hline
\end{tabular}

a. Dependent Variable: abs_RES

Sumber: Data diolah,2020

Analisis regresi linear berganda

Tabel 6.Hasil Analisis Regresi Linear Berganda

\begin{tabular}{llrrrrr}
\hline \multirow{2}{*}{ Model } & \multicolumn{2}{c}{$\begin{array}{c}\text { Unstandardized } \\
\text { Coefficients }\end{array}$} & \multicolumn{2}{c}{$\begin{array}{c}\text { Standardized } \\
\text { Coefficients }\end{array}$} & \multirow{2}{*}{ t } & \multirow{2}{*}{ Sig. } \\
\cline { 3 - 5 } & & \multicolumn{1}{c}{ B } & Std. Error & \multicolumn{1}{c}{ Beta } & & \\
\hline 1 & (Constant) & 27.418 & 4.952 & & 5.536 & .000 \\
& Motivasi & -.278 & .119 & -.259 & -2.340 & .023 \\
Kepuasan & .190 & .091 & .249 & 2.083 & .042 \\
Kerja & & & & & \\
& Disiplin Kerja & .316 & .107 & .353 & 2.942 & .005 \\
\hline
\end{tabular}

a. Dependent: Variable: kinerjar karyawan

Sumber: Data diolah,2020 


\section{$Y=27,418-0,278 X_{1}+0,190 X_{2}+0,316 X_{3}$}

Merujuk pada hasil dari persamaan regresi linear yang disajikan di atas, dengan demikian dapat dijelaskan bahwa: 1).Konstanta a ialah senilai 27,418 yang berarti bahwa bilamana variabel bebas atau independen dari motivasi $\left(\mathrm{X}_{1}\right)$, kepuasan kerja $\left(\mathrm{X}_{2}\right)$ serta disiplin kerja $\left(\mathrm{X}_{3}\right)$ dianggap konstan, dengan demikian ada peningkatan kinerja karyawan senilai 27,418. 2).Koefisien regresi dari variabel bebas atau independen dari motivasi $\left(\mathrm{X}_{1}\right)$ memperlihatkan sumbangan pengaruh negatif dan signifikan pada variabel terikat atau dependen dari kinerja karyawan (Y), hal semacam ini ditunjukkan dengan koefisien regresi senilai 0,278 dengan nilai signifikansi 0,023 pada taraf signifikansi $\alpha=5 \%(0,023<0,05)$. Hal semacam ini mengandung makna bahwa setiap penurunan variabel kinerja karyawan (Y) akan turun senilai 0,278, dengan asumsi bahwa variabel bebas atau independen yang lainnya ialah konstan atau tetap. 3).Koefisien regresi dari variabel bebas atau independen dari kepuasan kerja $\left(\mathrm{X}_{2}\right)$ memperlihatkan sumbangan pengaruh positif dan signifikan pada variabel terikat atau dependen dari kinerja karyawan (Y) senilai 0,190 dengan nilai signifikansi ialah 0,042 pada taraf signifikansi $\alpha=5 \%(0,042>0,05)$. Hal semacam ini mengandung makna bahwa setiap penurunan variabel kinerja karyawan (Y) akan naik senilai 0,042, dengan asumsi bahwa variabel bebas atau independen yang lainnya ialah konstan atau tetap. 4).Koefisien regresi dari variabel bebas atau independen dari disiplin kerja $\left(\mathrm{X}_{3}\right)$ memperlihatkan sumbangan pengaruh positif dan signifikan pada variabel terikat atau dependen dari kinerja karyawan (Y), hal ini ditujukan dengan koefisien regresi sebesar 0,316 dengan nilai signifikansi 0,005 pada taraf signifikansi $\alpha=5 \%(0,005<0,05)$. Hal semacam ini mengandung makna bahwa setiap kenaikan variabel kinerja karyawan (Y) akan naik senilai 0,316 dengan asumsi bahwa variabel bebas atau independen yang lainnya ialah konstan atau tetap.

\section{Hasil uji koefisien determinasi $\left(\mathbf{R}^{2}\right)$}

Berdasarkan Tabel 7 di atas bisa dilihat bahwa nilai dari $\mathrm{R}$ aialah senilai 0,579 yang memperlihatkan bahwa korelasi antara disiplin kerja, kepuasan kerja dan juga motivasi pada kinerja karyawan. Nilai dari adjusted $r$ square ialah senilai 0,335 mmemperlihatkan tingginya kontribusi atau peran dari variabel bebas atau independen dari motivasi, kepuasan kerja dan disiplin kerja mampu memprediksikan pengaruh pada variabel terikat atau dependen dari kinerja karyawan ialah senilai 33,5\%, dan sementara itu untuk yang lainnya yang senilai $66,5 \%$ (100\%-33,5\%) diprediksikan atau dijelaskan oleh variabel bebas atau independen lainnya yang tidak dimasukkan dalam pelaksanaan penelitian ini.

Tabel 7. Uji koefisien determinasi

\begin{tabular}{l|c|c|c|c} 
& & \multicolumn{2}{c}{ Model Summary } \\
Model & R & R Square & $\begin{array}{c}\text { Adjusted R } \\
\text { Square }\end{array}$ & $\begin{array}{c}\text { Std. Error of the } \\
\text { Estimate }\end{array}$ \\
\hline 1 & $.579^{\mathrm{a}}$ & .335 & .300 & 3.123 \\
\hline
\end{tabular}

a. Predictors: (Constant), Disiplin Kerja, Motivasi, Kepuasan Kerja

b. Dependent Variable: Kinerja Karyawan

Sumber: Data diolah,2020

\section{Uji hipotesis secara simultan (Uji F)}

Dalam pelaksanaan penelitian, $\mathrm{F}_{\text {tabel }}$ didapat dengan bantuan Microsoft Excel yaitu dengan perintah $=\mathrm{FINV}(\alpha ; \mathrm{df1} ; \mathrm{df} 2)($ Priyatno, 2013) . 
Keterangan :

$\alpha \quad=$ tingkat signifikansi $(5 \%)$

df1 $=\mathrm{k}-1=3-1=2$ (dimana $\mathrm{k}$ ialah jumlah dari variabel bebas atau independen)

df2 $=\mathrm{n}-\mathrm{k}=60-3=57$ (dimana $\mathrm{n}$ ialah jumlah responden, $\mathrm{k}$ adalah jumlah variabel independen). Dengan demikian. Berdasarkan proses tersebut, maka didapatkanlah nilai $F_{\text {tabel }}$ yaitu 3,16.

Tabel 8. Hasil uji F (uji simultan)

\begin{tabular}{llr|r|r|r|r}
\hline \multicolumn{7}{c}{ ANOVA $^{\text {a }}$} \\
\multicolumn{1}{l}{ Model } & $\begin{array}{c}\text { Sum of } \\
\text { Squares }\end{array}$ & \multicolumn{1}{c}{ df } & $\begin{array}{c}\text { Mean } \\
\text { Square }\end{array}$ & \multicolumn{1}{c}{ F } & \multicolumn{1}{c}{ Sig. } \\
\hline 1 & Regression & 275.554 & 3 & 91.851 & 9.418 & $.000^{\mathrm{b}}$ \\
& Residual & 546.180 & 56 & 9.753 & & \\
& Total & 821.733 & 59 & & & \\
\hline
\end{tabular}

a. Dependent variable: Kinerja karyawan

b. Predictors: (Constant), Disiplin kerja, Motivasi, Kepuasan kerja

Sumber: Data diolah,2020

Berdasarkan pada Tabel 8 dihasilkanlah nilai dari $F_{\text {hitung }}$ ialah senilai $(9,418)$ lebih tinggi dibanding pada nilai dari $F_{\text {tabel }}$ yang senilai (3.16) dari hasil diatas, dapat diindikasikan bahwa hasil dari pelaksanaan penelitian tersebut $\mathrm{H}_{0}$ ditolak, dan sedangkan untuk $\mathrm{H}_{1}$ diterima, hal ini didukung dengan nilai sig. senilau $0,000<0,05$. Dengan demikian bahwa variabel bebas atau independen dari disiplin kerja, kepuasan kerja dan juga motivasi secara simultan atau bersama-sama memberikan sumbangan pengaruh pada variabel terikat atau independen dari kinerja karyawan.

\section{Uji hipotesis secara parsial (Uji t)}

Pengujian statistif $t$ intinya ialah untuk memperlihatkan seberapa besar pengaruh secara parsial dari variabel bebas atau independen dalam menerangkan atau memprediksi variasi dari variabel terikat atau dependen (Ghozali, 2013). Dalam penelitian ini, ttabel didapat dengan bantuan Microsoft excel, yaitu dengan perintah $=\operatorname{TINV}(\alpha ; \mathrm{df})$ (Priyanto, 2013)

Keterangan : $\alpha=$ Tingkat signifikansi $(5 \%)$, df $=(\mathrm{n}-\mathrm{k}) ; \mathrm{n}=$ banyaknya sampel, $\mathrm{k}=$ banyaknya variabel bebas atau independen, dari perintah diatas, didapatkanlah nilai ttabel yaitu 2.00247.

Tabel 9.Hasil uji t (uji parsial)

\begin{tabular}{|c|c|c|c|c|c|c|}
\hline \multicolumn{7}{|c|}{ Coefficients $^{\mathrm{a}}$} \\
\hline & \multirow{2}{*}{ Model } & \multicolumn{2}{|c|}{$\begin{array}{l}\text { Unstandardized } \\
\text { Coefficients }\end{array}$} & \multirow{2}{*}{$\begin{array}{c}\begin{array}{c}\text { Standardized } \\
\text { Coefficients }\end{array} \\
\text { Beta }\end{array}$} & \multirow[t]{2}{*}{$\mathbf{t}$} & \multirow{2}{*}{ Sig. } \\
\hline & & B & Std. Error & & & \\
\hline \multirow[t]{4}{*}{1} & (Constant) & 27.418 & 4.952 & & 5.536 & .000 \\
\hline & Motivasi & -.278 & .119 & -.259 & -2.340 & .023 \\
\hline & $\begin{array}{l}\text { Kepuasan } \\
\text { Kerja }\end{array}$ & .190 & .091 & .249 & 2.083 & .042 \\
\hline & $\begin{array}{l}\text { Disiplin } \\
\text { Kerja }\end{array}$ & .316 & .107 & .353 & 2.942 & .005 \\
\hline
\end{tabular}

a. Dependent Variable: Kinerja Karyawan

Sumber: Data diolah,2020 
Nilai thitung dari variabel bebas bebas atau independen dari motivasi $(-2,340)$ lebih kecil dibanding pada nilai $t_{\text {tabel }}(-2.00247)$, atau nilai dari signifikansi $t$ dari variabel motivasi $(0,023)$ lebih rendah dibanding pada alpha $(0,05)$. Merujuk pada hasil yang diperoleh, dengan demikian $\mathrm{H}_{0}$ ditolak, dan sedangkan untuk $\mathrm{H}_{1}$ diterima dari variabel bebas atau independen dari motivasi. Oleh karena itu, variabel bebas atau independen dari motivasi, secara parsial memberikan sumbangan pengaruh signifikan dan negative pada variabel terikat atau dependen dari kinerja karyawan.

Nilai thitung dari variabel bebas bebas atau independen dari kepuasan kerja $(2,083)$ lebih tinggi dibanding pada nilai $t_{\text {tabel }}(2.00247)$, atau nilai dari signifikansi $t$ dari variabel kepuasan kerja $(0,042)$ lebih rendah dibanding pada alpha $(0,05)$. Merujuk pada hasil yang diperoleh, dengan demikian $\mathrm{H}_{0}$ ditolak, dan sedangkan untuk $\mathrm{H}_{1}$ diterima dari variabel bebas atau independen dari kepuasan kerja. Oleh karena itu, variabel bebas atau independen dari kepuasan kerja, secara parsial memberikan sumbangan pengaruh signifikan dan positif pada variabel terikat atau dependen dari kinerja karyawan.

Nilai thitung dari variabel bebas bebas atau independen dari disiplin kerja $(2,942)$ lebih tinggi dibanding pada nilai $t_{\text {tabel }}$ (2.00247), atau nilai dari signifikansi t dari variabel bebas atau independen dari disiplin kerja $(0,005)$ lebih rendah dibanding pada alpha $(0,05)$. Merujuk pada hasil yang diperoleh, dengan demikian $\mathrm{H}_{0}$ ditolak, dan sedangkan untuk $\mathrm{H}_{1}$ diterima dari variabel bebas atau independen dari disiplin kerja. Oleh karena itu, variabel bebas atau independen dari disiplin kerja, secara parsial memberikan sumbangan pengaruh signifikan dan positif pada variabel terikat atau dependen dari kinerja karyawan.

\section{Pengaruh motivasi terhadap kinerja karyawan}

Pada hipotesis pertama $\left(\mathrm{H}_{1}\right)$ yang memperlihatkan bahwa variabel bebas atau independen dari motivasi memberikan sumbangan pengaruh signifikan pada kinerja yang dihasilkan oleh pekerja tersebut tidak terbukti. Hal ini dipertujukkan dengan nilai dari $t_{\text {hitung }}$ yang lebih tinggi dibanding pada $t_{\text {tabel }}(-2,340>-2,00247)$ dan sedangkan untuk nilai dari signifikansinya lebih rendah dibanding pada $0,05(0,023>0,05)$. Dengan demikian bisa dihasilkan suatu simpulan bahwa variabel bebas atau independen dari motivasi secara parsial memberikan sumbangan pengaruh negatif dan signifikan pada kinerja yang dihasilkan karyawan.

Motivasi kerja adalah suatu kondisi dalam diri pribadi setiap karyawan pada perusahaan yang mendorong merka dalam bekerja, sehingga semakin bagus motivasi dari karyawan maka akan semakin bagus pula semngat kerja sehingga menghasilkan kinerja yang tinggi pula.

Hal semacam ini dikaiibatkan oleh tingginya motivasi dalam bekerja, para pekerja akan merasa tegang dalam melaksanakan pekerjaan yang menjadi tanggung jawabna, dengan demikian menyebabkan perasaan yang tidak aman dan nyaman yang akan memberikan pengaruh pada penurunan hasil kinerja yang dihasilkan pekerja. Namun sebaliknya yang akan terjadi bilamana motivasi yang dipunyai oleh para pekerja dalam bekerja tersebut mengalami penurunan, dengan demikian para pekerjakan akan merasakan kenyamanan dalam melaksanakan pekerjaan, dengan demikian hasil dari kinerja yang akan dihasilkan pekerja akan mengalami peningkatan. Pekerja yang melaksanakan aktivitas kerja berada dalam tekanan yang diakibatkan oleh peraturan yang ketat akan membuat kemapuan dari pekerja tersebut dalam melaksanakan 
pengeksplorasian kinerja bilamana diperbandingkan terhadap pegawai yang diberikan peraturan yang tidak terlalu mengikat.

Motivasi yang tinggi dari perusahaan tidak diimbangi dengan kinerja yang tinggi dari karyawan, disimpulkan oleh penulis perbedaan dari fenomena dengan hasil analisis statistik dikarenakan dua masalah inti yaitu adanya variabel lain yang membuat kinerja karyawan menurun dan motivasi kerja yang sebenarnya tidak terlalu tinggi dimiliki oleh karyawan hal tersebut dibuktikan dengan rata-rata jawaban responden yang masuk dalam kategori sedang.

\section{Pengaruh kepuasan kerja terhadap kinerja karyawan}

Dalam hipotesis pertama $\left(\mathrm{H}_{2}\right)$ yang memperlihatkan bahwa variabel bebas atau independen dari kepuasan kerja memberikan sumbangan pengaruh signifikan pada kinerja yang dihasilkan oleh pekerja tersebut terbukti. Hal ini dipertujukkan dengan nilai dari thitung yang lebih tinggi dibanding pada $t_{\text {tabel }}(2,083<2,00247)$ dan sedangkan untuk nilai dari signifikansinya lebih rendah dibanding pada $0,05(0,042>0,05)$. Dengan demikian bisa dihasilkan suatu simpulan bahwa variabel bebas atau independen dari motivasi secara parsial memberikan sumbangan pengaruh signifikan dan positif pada kinerja yang dihasilkan karyawan. Dengan demikian memperlihatkan bahwa variabel bebas atau independen dari kepuasan kerja memberikan sumbangan pengaruh signifikan pada kinerja karyawan.

Hal semacam ini diperkuat dengan hasil dari penelitian yang dilaksanakan Sulistyawati dan Indrayani (2012) yang mengemukakan bahwa variabel bebas atau independen dari kepuasan kerja memberikan sumbangan pengaruh signifikan pada kinerja karyawan. Hasil dari penelitian ini juga memperkuat hasil penelitian yang dilaksanakan Dewi dan Mulyantono (2012) menghasilkan suatu simpulan bahwa variabel bebas atau independen dari kepuasan kerja memberikan sumbangan pengaruh signifikan dan positif pada kinerja karyawan. Ini juga diperkuat dengan hasil dari penelitian yang dilaksanakan Nugroho dan Kuswardani (2011) yang menjelaskan bahwa variabel bebas atau independen dari kepuasan kerja memberikan sumbangan pengaruh positif pada kinerja karyawan, hal ini disebabkan bahwa pekerja akan merasa puas, senang dan juga suka terhadap pekerjaan yang dijalani. Hal semacam ini bisa berlangsung disebabkan bahwa kepuasan mampu menaikkan rasa stimulus agar berkerja dengan lebih giat dan baik, lingkungan yang tidak terjadi konflik dan nyaman maka akan membuat para karyawan memberikan kesetiaan dan loyalitas yang baik pada perusahaan di mana mereka bekerja. Bilamana seorang pekerja mempunyai semangat atau motibasi dalam melaksanakan pemenuhan kebutuhan, dengan demikian akan menghasilkan kepusan dalam bekerja dan memberikan dampak yang baik pada kinerja yang dihasilkan.

\section{Pengaruh disiplin kerja terhadap kinerja karyawan}

Pada hipotesis pertama $\left(\mathrm{H}_{3}\right)$ yang menyatakan bahwa disiplin kerja berpengaruh secara signifikan terhadap kinerja karyawan terbukti. Hal ini ditunjukkan dengan nilai $t_{\text {hitung }}>\mathrm{t}_{\text {tabel }}(2,942<2,00247)$ dan nilai sig $<0,05(0,005>0,05)$. Sehingga dapat disimpulkan bahwa secara parsial kepuasan kerja berpengaruh positif dan signifikan terhadap kinerja karyawan.

Dalam hipotesis pertama $\left(\mathrm{H}_{3}\right)$ yang memperlihatkan bahwa variabel bebas atau independen dari disiplin kerja memberikan sumbangan pengaruh signifikan pada kinerja yang dihasilkan oleh pekerja tersebut terbukti. Hal ini dipertujukkan dengan nilai dari 
$t_{\text {hitung }}$ yang lebih tinggi dibanding pada tabel $(2,942<2,00247)$ dan sedangkan untuk nilai dari signifikansinya lebih rendah dibanding pada $0,05(0,042>0,05)$. Dengan demikian bisa dihasilkan suatu simpulan bahwa variabel bebas atau independen dari motivasi secara parsial memberikan sumbangan pengaruh signifikan dan positif pada kinerja yang dihasilkan karyawan. Dengan demikian memperlihatkan bahwa variabel bebas atau independen dari kepuasan kerja memberikan sumbangan pengaruh signifikan pada kinerja karyawan.

Penelitian ini disiplin berpengaruh secara signifikan terhadap kinerja, penelitian ini sejalan dengan penelitian yang dikalakukan oleh Labudo (2013), bahwa disiplin kerja berpengaruh terhadap produktivitas/kinerja karyawan sehingga dapat meningkatkan produktivitas/kinerja karyawan. Dalam penelitian yang di lakukan oleh Korompot dan Robiansyah (2012), mengatakan bahwa disiplin kerja positif berpengaruh terhadap kinerja karyawan. Hasil yang sama juga ditunjukkan penelitian yang dilakukan oleh Munawaroh (2012) menyimpulkan bahwa disiplin kerja memiliki pengaruh secara langsung terhadap kinerja. Hal ini dikarenakan tingkat disiplin juga mempengaruhi hasil kinerja dari SDM yang ada, dengan kata lain tanpa disiplin tingkat pengaturan waktu yang ada tidak akan stabil sehingga kinerja yang ada akan tergangggu. Hasil penelitian ini mendukung hasil penelitian yang dilakukan oleh Rakasiwi (2014) tentang pengaruh motivasi, kepuasan kerja, dan disiplin kerja terhadap kinerja pegawai pada satuan polisi pamong praja Kabupaten Karanganyer yang menyatakan bahwa disiplin kerja berpengaruh signifikan terhadap kinerja karyawan. Hal ini disebabkan karena disiplin kerja yang tinggi, para pegawai merasakan ketegangan dalam melakukan pekerjaannya, sehingga menimbulkan rasa tidak nyaman yang akan berpengaruh terhadap menurunnya kinerja pegawai. Sebaliknya, jika disiplin kerja meningkat, maka para pegawai akan merasa nyaman dalam bekerja, sehingga kinerja pegawai semakin meningkat. Begitu juga dengan penelitian Abdillah dan Wajdi (2011) menyatakan disiplin kerja berpengaruh positif terhadap kinerja pegawai.

\section{Pengaruh motivasi, kepuasan kerja dan disiplin kerja terhadap kinerja karyawan}

Hasil dari penelitian ini menyatakan bahwa secara bersamaan motivasi kerja, disiplin kerja dan kepuasan berpengaruh secara signifikan terhadap kinerja yang dihasilkan oleh PT. Indonesia Comnets Plus. Hal ini sejalan dengan pendapat tentang Kinerja yang baik selalu membawakan dampak yang positif, Wibowo (2010:8), mengatakan bahwa kinerja adalah lebih melihat manajemen kinerja sebagai sarana untuk mendapatkan hasil yang lebih baik dari organisasi untuk hasil yang lebih baik dari organisasi, tim, individu dengan cara memahami dan mengelola kinerja dalam suatu kerangka tujuan, standar, persyaratan artibut yang disepakati.

\section{KESIMPULAN DAN SARAN}

\section{Kesimpulan}

Pengujian hasil secara parsial menunjukkan bahwa motivasi berpengaruh negatif dan signifikan terhadap kinerja karyawan pada PT. Indonesia Comnets Plus. Dimana variabel motivasi memiliki nilai $t_{\text {hitung }}>\mathrm{t}_{\text {tabel }}(-2,340>-2,00247)$ dan nilai sig $<0,05$ $(0,023>0,05)$.

Pengujian secara parsial menunjukkan bahwa kepuasan kerja berpengaruh positif terhadap kinerja karyawan pada PT. Indonesia Comnets Plus. Dimana variabel kepuasan 
kerja memiliki nilai $t_{\text {hitung }}>t_{\text {tabel }}(2,083<2,00247)$ dan nilai sig $<0,05(0,042>0,05)$.

Pengujian secara parsial menunjukkan bahwa Disiplin berpengaruh positif dan signifikan terhadap kinerja karyawan pada PT. Indonesia Comnets Plus. Dimana variabel Disiplin memiliki nilai $t_{\text {hitung }}>\mathrm{t}_{\text {tabel }}(2,942<2,00247)$ dan nilai sig $<0,05(0,005>$ 0,05).Hasil dari penelitian ini menyatakan bahwa secara bersamaan Motivasi kerja, Disiplin kerja dan Kepuasan berpengaruh secara signifikan terhadap kinerja yang dihasilkan oleh PT. Indonesia Comnets Plus. Dengan nilai F hitung $(9,418)$ lebih besar dari $F_{\text {tabel }}$ (3.16) dan nilai sig. sebesar $0,000<0,05$.

\section{Saran}

Dalam penelitian selanjutnya diharapkan menggunakan variabel yang lebih bervariasi dengan menambah variabel lainnya yang juga memiliki pengaruh terhadap kinerja karyawan agar hasil penelitian lebih lengkap dan maksimal.

Penelitian selanjutnya sebaiknya tidak hanya menggunakan metode survei dengan cara menyebarkan kuesioner saja, tetapi juga ditambah dengan melakukan wawancara secara langsung, agar peneliti dapat melihat langsung bagaimana responden memberikan jawaban.

Bagi pihak manajemen, hasil penelitian menunjukkan motivasi kerja PT. Indonesia Comnets Plus rendah, hal ini perlu diperhatikan oleh pihak manajemen misalnya dengan cara meningkatkan insentif, atau dengan bentuk penghargaan lainnya sehingga dapat meningkatkan kinerja karyawan.

\section{DAFTAR PUSTAKA}

Ahmed, Ishfaq, Nawaz, (2010). Effects of motivational factors on employees job satisfaction a case study of University of the Punjab. Pakistan. International Journal of Business and Management. 5(3), 70-80.

Ardana, Komang, Mujiati, Ni Wayan, Utama, I Wayan, (2012). Manajemen sumber daya manusia. Graha Ilmu: Yogyakarta

Bangun, Wilson, (2012). Manajemen sumber daya manusia, Erlangga: Bandung.

Ghozali. Imam, (2013). Aplikasi Analisis Multivariate Dengan Program SPSS 21. Badan Penerbitan Universitas Diponegoro: Semarang.

Fahmi, (2013). Manajemen Kinerja Teori dan Aplikasi, Alfabeta: Bandung

Fahmi, (2013). Perilaku Organisasi Teori, Aplikasi, dan Kasus. Alfabeta: Bandung

Trisnowati, Juni. (2013). Pengaruh Motivasi dan Disiplin Kerja terhadap Kinerja

Pegawai PT BPR Kartasura Saribumi Cabang Masaran.Ekonomi Bisnis dan Kewirausahaan, II(2), 24-35

Shaylendra, Kenda, Laksa., Mochamad Djudi., \& Gunawan Eko Nurtjono.(2015). Pengaruh motivasi kerja dan disiplin kerja terhadap kinerja karyawan (studi pada karyawan perusahaan daerah (pd) bank perkreditan rakyat (bpr) bank daerah lamongan. Jurnal Administrasi Bisnis, 22(1), 1-7

Hasibuan, (2012). Manajemen sumber daya manusia (Edisi Revisi). PT. Bumi Aksara: Jakarta

Wijono, (2010). Dalam suatu bidang gerak psikologi sumber daya manusia (Edisi Revisi). PT. Adhitya Andrebina Agung: Jakarta

Sugiyono, (2013). Metode penelitian bisnis. CV. Alfabeta: Bandung 
Susilaningsih, Nur . (2008). Pengaruh kepemimpinan, disiplin, motivasi, pengawasan dan lingkungan kerja terhadap kinerja pegawai (Studi pada badan perencanaan pembangunan daerah Kabupaten Wonogiri). Excellent. 1(2), 1-19.

Sutrisno, Fathoni, Minarsih, (2016). Pengaruh Motivasi dan Disiplin Kerja terhadap Kinerja Pegawai di Kantor Satuan Polisi Pamong Praja Kota Semarang. Journal of Management, 2(2).

Sugiyono. (2004). Metode penelitian bisnis: Penerbit CV. Alfabeta: Bandung. 